\title{
IMPLEMENTASI VOICE OVER INTERNET PROTOCOL (VOIP) BERBASIS LINUX (Studi Kasus SMK Negeri 03 Bengkulu)
}

\author{
Muntahanah $^{1}$, Rozali Toyib ${ }^{2}$, Islan Wardiman ${ }^{3}$ \\ 1,2,3 Program Studi Informatika, Fakultas Teknik, Universitas Muhamamadiyah Bengkulu \\ Jl. Bali Po. Box, 118 Kota Bengkulu 38119 Indonesia
}

(Telp: 0736-22765; fax: 0736-26161)

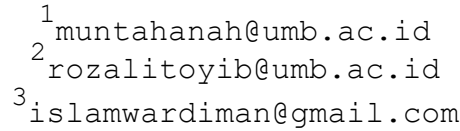

Abstrak: Teknologi saat ini berkembang dengan pesat khususnya dalam bidang telekomunikasi, pada dasarnya semua orang yang terhubung ke jaringan mereka dapat bertukar informasi dan data antara satu orang dengan yang lain, baik berupa gambar, suara, video, teks dan yang lainnya, namun jika kita menggunakan panggilan telepon tradisional, selain tarif yang mahal juga letak geografis menentukan besar kecilnya biaya yang harus dikeluarkan. Voice Over Internet Protocol (VoIP) merupakan sebuah teknologi inovasi yang menjadikan jaringan internet ataupun jaringan lokal komputer, sebagai media transmisi paket data suara agar pengguna dapat berkomunikasi satu sama lain. Hasil pengujian pada pengujian Alpha Delay (Waktu Tunggu) telpon VOIP lebih Singkat dibandingkan dengan telpon whatsapp adalah 17 detik. Jadi telpon voip lebih unggul 14 Detik dari telpon Whatsapp diambil dari selisih delay whatsapp dan voip yaitu 17 Detik - 3 Detik = 14 Detik, Pada pengujian Beta Semua client telah terhubung dengan server dan client lainnya.

Kata Kunci: Voice Over Internet Protocol, informasi, alfa, beta, delay.

\begin{abstract}
Technology is currently developing rapidly, especially in the field of telecommunications, basically all people connected to their networks can exchange information and data from one person to another, whether in the form of images, sound, video, text and others, but if we use Traditional telephone calls, in addition to expensive tariffs, also the geographical location determines the size of the costs to be incurred. Voice Over Internet Protocol (VoIP) is an innovative technology that makes the internet network or computer local network, as a medium of transmission of voice data packets so that users can communicate with each other. The test results on the Alpha Delay test (Waiting Time) VOIP telephone is shorter than whatsapp phone is 17 seconds. So voip phone is superior 14 seconds than Whatsapp phone is taken from the difference between whatsapp and voip delay which is 17 seconds -3 seconds $=14$ seconds, in beta testing all clients have been connected with the server and other clients.
\end{abstract}

Keywords: Voice Over Internet Protocol, information, alfa, beta, delay

\section{Pendahuluan}

Teknologi saat ini berkembang dengan pesat khususnya dalam bidang telekomunikasi. Pada dasarnya semua orang yang terhubung ke jaringan mereka dapat bertukar informasi dan data antara satu orang dengan yang lain, baik berupa gambar, suara, video, teks dan yang lainnya. Teknologi untuk bertukar suara sudah banyak digunakan oleh masyarakat, salah satunya adalah telepon, yaitu berkomunikasi menggunakan telepon kabel (Telkom) atau pun telepon genggam semua orang dapat berkomunikasi di dalamnya. Namun jika kita menggunakan panggilan telepon tradisional, selain tarif yang mahal juga letak geografis menentukan besar kecilnya biaya yang harus dikeluarkan 
Jurnal Pseudocode, Volume VII Nomor 1, Februari 2020, ISSN 2355-5920, e-ISSN 2655-1845 www.ejournal.unib.ac.id/index.php/pseudocode

Penyampaian informasi di SMK Negeri 03 Bengkulu masih menggunakan manual dan semi teknologi hal ini dinilai kurang efektif karena membutuhkan tenaga dan biaya yang tinggi untuk melakukan hubungan komunikasi lokal. Belum adanya alternative untuk menyampaikan informasi secara efektif dengan tenaga yang cukup serta secara gratis dengan memanfaatkan fasilitas yang ada.

Munculnya teknologi Voice Over Internet Protocol (VoIP) yang murah untuk berkomunikasi baik suara maupun video call menggunakan internet atau jaringan lokal yang berjalan melalui jaringan IP (Internet Protocol), ini membuat sebuah keuntungan sendiri bagi kalangan yang selalu membutuhkan alat komunikasi di lingkungan kerjanya, terutama di lingkungan pendidikan atau sekolah karena biaya lebih murah. Teknologi telepon ini mengubah suara menjadi kode digital melalui jaringan paket data, bukan sirkuit analog seperti telepon biasa.

VoIP (Voice over Internet Protocol). Voice over Internet Protocol (juga disebut VoIP, IP Telephony, Internet telephony atau Digital Phone) adalah teknologi yang memungkinkan percakapan suara jarak jauh melalui media internet, Data suara diubah menjadi kode digital dan dialirkan melalui jaringan yang mengirimkan paket-paket data dan bukan lewat sirkuit analog telepon biasa [1]. Voice Over Internet Protocol (VoIP) merupakan sebuah teknologi inovasi yang menjadikan jaringan internet ataupun jaringan lokal komputer, sebagai media transmisi paket data suara agar pengguna dapatberkomunikasi satu sama lain [2]. Saat ini teknologi Voice Over Internet Protocol (VoIP) banyak digunakan manusia untuk berkomunikasi. VoIP memungkinkan pengiriman paket data suara dari satu tempat ke tempat lainnya melalui jaringan berbasis Internet Protocol (IP), seiring dengan semakin murahnya biaya berlangganan broadband internet maka biaya percakapan melalui teknologi VoIP pun menjadi murah [3].

Sistem Operasi Linux yang bisa untuk networking, yaitu salah satunya Linux Redhat 9 yang terbukti murah dan handal dalam melakukan kerjanya sebagai router. Banyak digunakan di ISP (Internet Service Provider), router pada warnet, Gateway pada Kantor [4]. GNU adalah sebuah sistem operasi yang sepenuhnya terdiri dari perangkat lunak bebas, merupakan akronim untuk GNU's Not Unix (GNU Bukanlah Unix). Proyek ini memperkenalkan konsep copyleft yang pada dasarnya mengadopsi prinsip copyright, namun prinsip tersebut digunakan untuk menjamin kebebasan berkreasi. Jaminan tersebut berbentuk pelampiran kode sumber (source code), serta pernyataan bahwa perangkat lunak tersebut boleh dimodifikasi asalkan tetap mengikuti prinsip copylef [5].

\section{LANDASAN TEORI}

\section{A. Voice Over Internet Protocol (VoIP)}

VoIP (Voice Over Internet Protocol) adalah sebuah teknologi yang mampu melewatkan trafik suara, video dan data yang berbentuk paket melalui jaringan IP. Penggunaan jaringan IP memungkinkan penghematan biaya dikarenakan tidak perlu membuat infrastruktur baru untuk komunikasi suara dan penggunaan lebar data (bandwith) yang lebih kecil dibandingkan dengan telepon biasa [6].

Penggunaan telepon berbasis VoIP memberi banyak keuntungan terutama dari segi biaya jelas lebih murah dari biaya telepon tradisional, karena jaringan IP bersifat global. Hal ini karena VoIP dapat dipasang pada setiap Ethernet dan IP address, tidak seperti telepon tradisional yang harus mempunyai port tersendiri di Sentral atau PBX. Dalam merencanakan suatu jaringan VoIP, harus memiliki suatu server yang berfungsi sebagai IP PBX [7]. 
Jurnal Pseudocode, Volume VII Nomor 1, Februari 2020, ISSN 2355-5920, e-ISSN 2655-1845 www.ejournal.unib.ac.id/index.php/pseudocode

\section{E. Jaringan Komputer}

Komponen jaringan adalah komponen yang memberikan dukungan terhadap fungsi kerjanya sistem jaringan yang meliputi model jaringan, topologi, media transmisi, arsitektur jaringan dan protocol adapun Jenis Jaringan berdasarkan kebutuhan [8]. istilah jaringan komputer adalah mengartikan himpunan interkoneksi (interconnected) sejumlah komputer autonomous [9]. Jaringan komputer merupakan kumpulan komputer, printer dan peralatan lainnya yang terhubung antara satu dengan yang lain. Data dan informasi dialirkan melalui melalui kabel-kabel atau tanpa kabel sehingga memungkinkan pengguna jaringan komputer dapat saling bertukar dokumen dan data, atau bahakan bersama-sama menggunakan hardware/ software yang terhubung dengan jaringan [10].

\section{F. Jaringan Peer To Peer}

Jaringan peer to peer menhubungkan beberapa komputer dalam sebuah jaringan .pertukaran data dapat dilakukan antar komputer yang terhubung tanpa perantara komputer server.masing -masing komputer dapat berperan sebagai komputer server sekaligus sebagai komputer client [11]. Jaringan peer to peer atau teknologi "ujung" ke "ujung" yang pertama kali diperkenalkan sebagai media yang membantu pengguna untuk saling bmencari dan berbagi data. Misalkan saja ingin melakukan pengambilan data yang besar dari PC dengan sistem operasi ubuntu sedangkan tidak mempunyai media transfer data yang besar maka dengan jaringan peer to peer ini proses pengiriman data akan semakin mudah dan menghemat waktu, tanpa harus membagi data tersebut menjadi beberapa bagian untuk dipindahkan [12]. Diperkenalkan pada tahun 1999 oleh Napster, sebuah layanan untuk berbagi musik. Sejak saat itu aplikasi untuk peer-to-peer (P2P) mulai banyak dikembangkan, diantaranya: Gnutell, eDonkey2000, Kazaa,
FastTrack, Freenet, Chord, CAN dan BitTorrent [13]

\section{G. Jaringan Berbasi server}

Jaringan berbasis Server atau Client - Server didefenisikan dengan kehadiran server didalam suatu jaringan yang menyediakan mekanisme pengamanan dan pengelolaan jaringan tersebut jaringan ini terdiri dari banyak client dan satu atau lebih server [14].

\section{H. Jaringan Multi Protocol Label Switching} (MPLS)

Multi Protocol Label Switching adalah salah satu metoda yang dapat digunakan untuk tuning jaringan agar lebih meningkatkan performa jaringan. MPLS merupakan teknik untuk mengintegrasikan IP dengan ATM dalam jaringan backbone yang sama. Teknologi MPLS mempersingkat proses - proses yang ada di IP routing tradisional dengan mengandalkan sistem label switching [15]. Metode MPLS membangkitkan gagasan untuk mengubah paradigma routing di layer-layer jaringan yang ada selama ini, dan mengkonvergensikannya ke dalam sebuah metode, yang dinamai GMPLS. GMPLS melakukan forwarding data menggunakan VC tingkat rendah dan tingkat tinggi di $\mathrm{SDH}$, dan panjang-gelombang di WDM, dan serat-serat dalam FO; terpadu dengan routing di layer IP [16].

\section{Jalu Komunikasi VOIF}

Pengiriman sebuah sinyal ke remote destination dapat dilakukan secara digital, yaitu sebelum dikirim data yang berupa sinyal analog, diubah dulu ke bentuk data digital dengan ADC (analog to digital converter), kemudian ditransmisikan, dan dipenerima dipulihkan kembali menjadi data analog dengan DAC (digital to analog converter). Begitu juga dengan VoIP, digitalisasi voice dala bentuk packet data, 
dikirimkan dan dipulihkan kembali dalam bentuk voice dipenerima. Voice diubah dulu kedalam format digital karena lebih mudah dikendalikan dalam hal ini dapat dikompresi, dan dapat diubah keformat yang lebih baik dan data digital lebih tahan terhadap noise daripada analog [17].

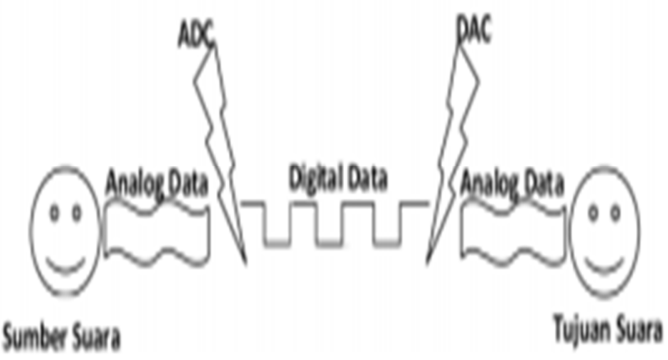

Gambar 1. Cara Kerja VOIF

J. Session Initiation Protocol (SIP)

Session Initiation Protocol (SIP) merupakan sebuah protokol standart multimedia dimana merupakan produk dari Internet Engineering Task Force (IETF) dan telah digunakan menjadi suatu standart penggunaan VoIP. SIP merupakan protokol yang berada pada layer aplikasi dimana mendefinisikan proses awal, pengubahan, dan pengakhiran (pemutusan) suatu sesi komunikasi multimedia. Dapat dikatakan juga SIP ini memiliki karakteristik client-server, dimana berarti request diberikan oleh client dan request ini diberikan ke server. Kemudian server mengolah request dan memberikan tanggapan terhadap request yang diberikan client. Request dan tanggapan terhadap request tersebut disebut transaksi SIP [18].

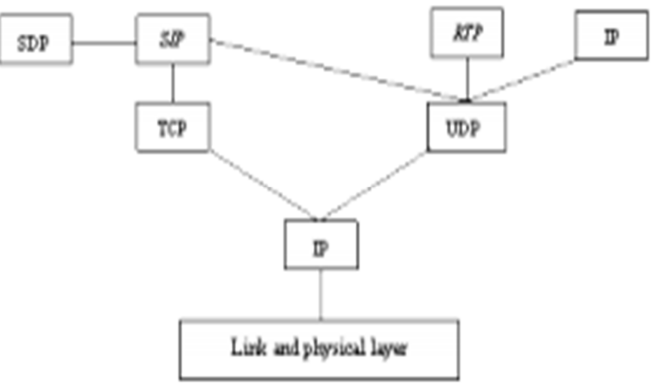

Gambar 2. Topologi Protokol Jaringan
K. Coder - Decoder

Codec (Coder-Decoder), Pada prinsipnya pengodean suara merupakan pengalihan kode analog menjadi kode digital agar suara dapat dikirim dalam jaringan komputer. Pengodean inilah yang disebut dengan istilah codec. Contoh beberapa jenis codec yang ada saat ini diantaranya: GSM, G.711, G.722 dan lain-lain [19].

L. Internet Protocol (IP)

Internet Protocol (IP) merupakan metode yang digunakan untuk mengirim data dari satu komputer ke komputer lain melintasi jaringan .setiap komputer (di kenal dengan host )memiliki paling tidak satu IP addres yang berguna untuk memperkenalkan diri nya kekomputer lain di dalam jaringan [20].

\section{Linux Trixbox CE}

Trixbox (Asterisk@home) adalah VoIP Phone System yang berbasiskan sistem open source PBX (private Brance Excange) yang ketika sekali di-install kepad suatu PC dengan interface yang sesuai maka akan dapat di gunkan sebagai full feature PBX untuk pengguna rumahan, lembaga, dan lain sebagainya. Trixbox sangat terkenal karena mengkombinasikan paket-paket Open Source Telepon terbaik yang disertakan di dalam sistem operasi tersebut. Dahulu seorang user dituntut untuk menjadi seorang programmer jika ingin mengimplementasikan VoIP karena User Interface yang tidak Friendly. oleh karena itu untuk mengatasi masalah seperti itu diluncurkannya Trixbox dengan penggunaan yang sangat mudah karena menu utama yang berbasiskan web browsure untuk menkonfigurasi dan mengatur sistem, serta pasket-paket untuk VoIP Server dijadikan dalam satu bundle dengan operating system CentOS sehingga menjadi sistem Trixbox CE [21]. 
Jurnal Pseudocode, Volume VII Nomor 1, Februari 2020, ISSN 2355-5920, e-ISSN 2655-1845 www.ejournal.unib.ac.id/index.php/pseudocode

N. Virtual Private Network

Virtual Private Network (VPN) adalah sebuah teknologi jaringan komputer yang dikembangkan oleh perusahaan skala besar yang menghubungkan antar jaringan diatas jaringan lain menggunakan internet yang membutuhkan jalur privacy dalam komunikasinya. Dalam jaringan VPN, internet adalah sebuah media pendukung yang menjadi fasilitas dalam proses komunikasinya [22].

\section{METODE PENELITIAN}

A. Tempat dan Waktu Penilitian

Tempat penelitian di laksanakan di SMKN 03 Kota Bengkulu yang beralamatkan di JL.Jati No.42 Sawah Lebar Bengkulu

B. Metode Pengumpulan Data

1. Observasi, yaitu memperoleh data dengan melakukan pengamatan langsung teknologi jaringan yang digunakan di SMKN 03 Kota Bengkulu

2. Wawancara, yaitu pengumpulan data dengan melakukan wawancara secara langsung kepada Pimpinan dan Staf karyawan

3. Studi pustaka, yaitu membaca, mempelajari buku-buku literatur yang berhubungan dengan penelitian

4. Studi Litelatur, yaitu cara mengumpulkan data dengan mempelajari buku-buku, teori baik buku tertulis maupun buku.
C. Activity Diagram

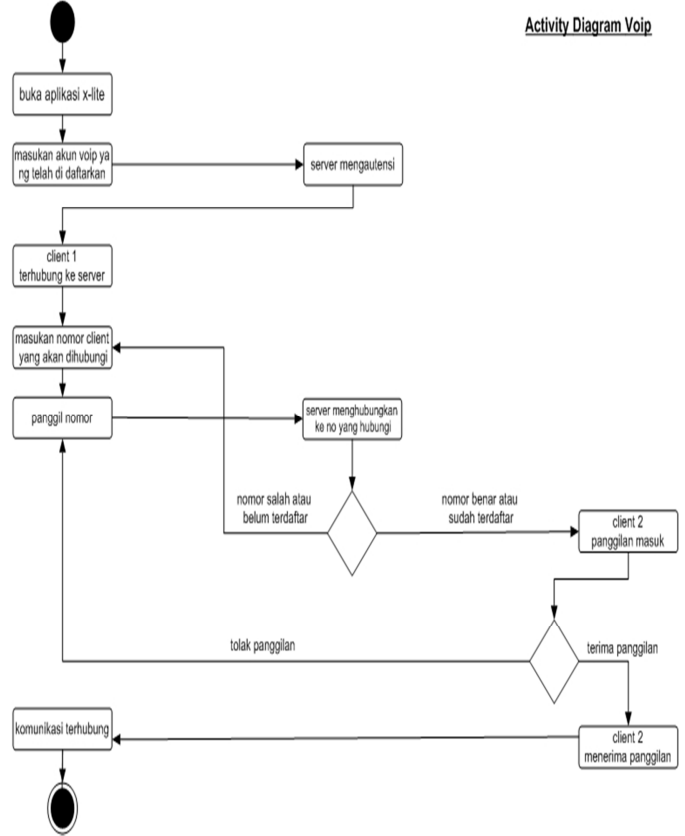

Gambar 3. Activity Diagram Penerapan VOIP Pada SMK N 3 Kota Bengkulu

D. Use Case Diagram

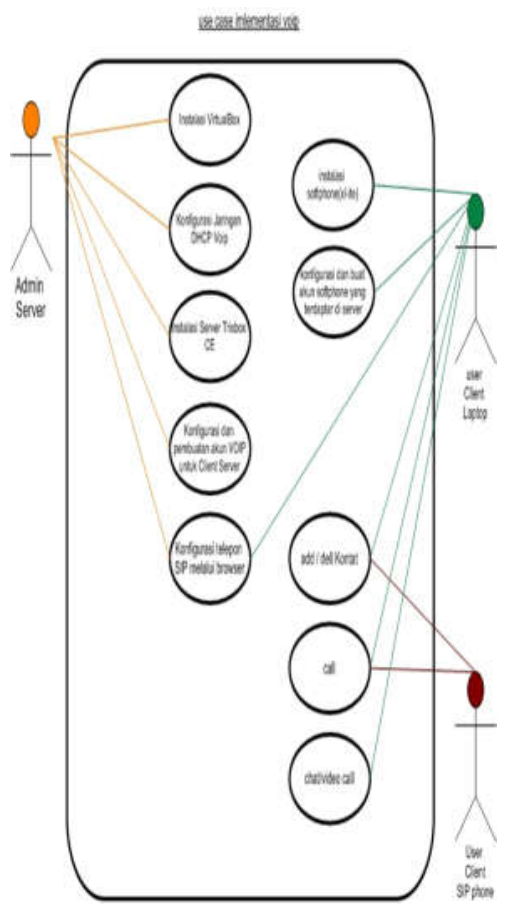

Gambar 4. Use Case Diagram Implementasi VOIP SMKN 03 Bengkulu 
E. Blok Diagram

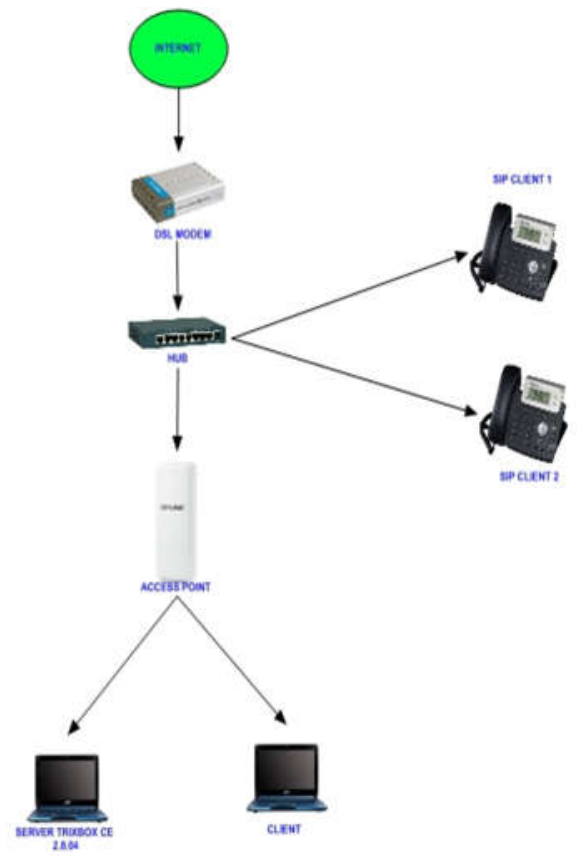

Gambar 5. Blok Diagram VOIP SMKN 03 Bengkulu

\section{HASIL DAN PEMBAHASAN}

A. Hasil

\section{Proses instalasi Linux Trixbox $C E$}

Proses instalasi Linux trixbox CE berjalan dengan baik ditadai dengan munculnya IP pada eth0 misal http// 192.168.56.101 yang sudah dapat diremote dari browser. Seperti yang tampak pada gambar 6 berikut :

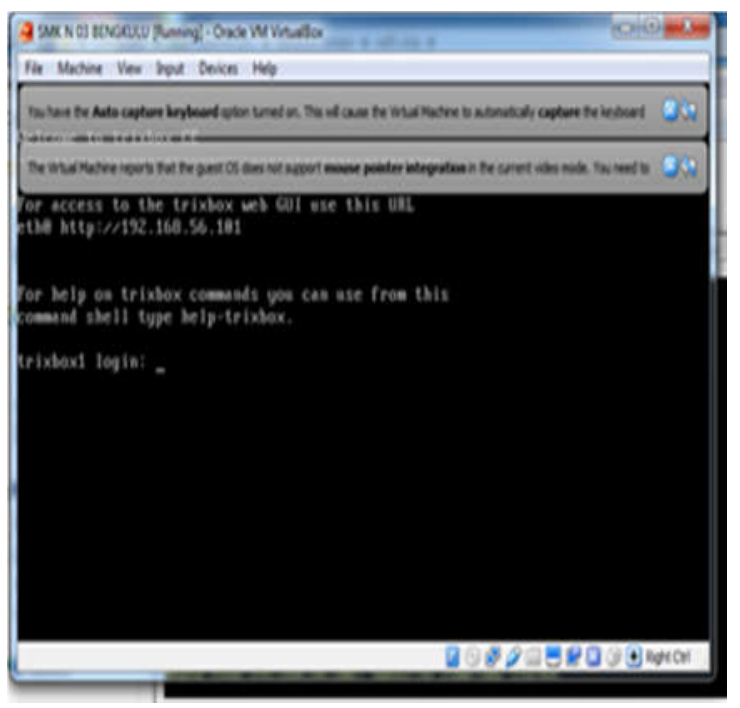

Gambar 6. Proses Instalasi Linux Trixbox CE

\section{Berhasil}

\section{Proses pembuatan akun client VOIP pada} Linux Trixbox CE

Hasil dari pembuatan akun client voip telah berhasil dibuat berupa beberapa akun yang terdaftar untuk dimasukkan ke client seperti gambar 7 berikut :

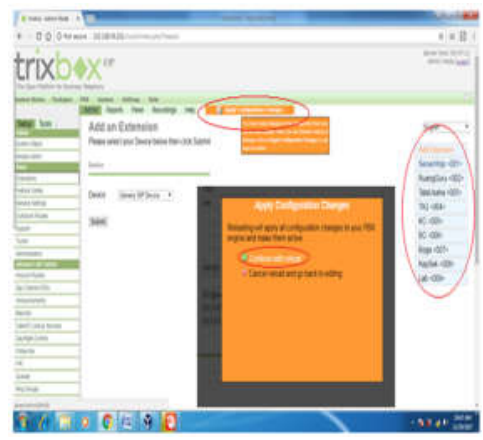

Gambar 7. Pembuatan Akun Client VOIP berhasil

\section{Konektivitas dari Client menuju Server VOIP}

Hasil dari konektivitas yang didapat dari implementasi voice over internet protocol voip berbasis Linux ini semua client dapat terhubung dengan baik ke server hal ini di buktikan dengan hasil perintah ping yang telihat pada gambar 8 berikut.

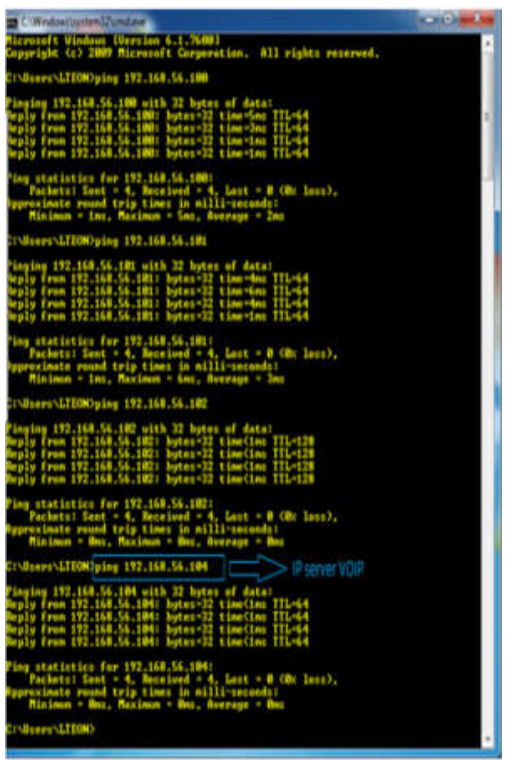

Gambar 8. Konektivitas Client Ke Server 


\section{Proses instalasi dan konfigurasi softphone}

Hasil untuk instalasi dan konfigurasi softphone berhasil dengan ditandai dengan adanya status Available pada xliteyang menyatakan bahwa software telah siap digunakan serta telah terhubung dengan server trixbox.

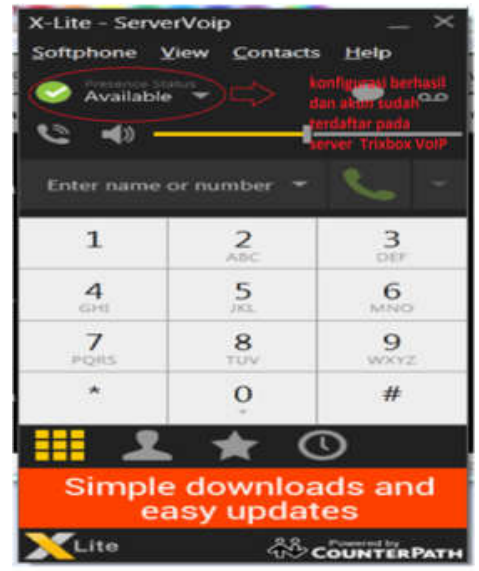

Gambar 9. Instalasi dan konfigurasi Softphone berhasil

\section{Panggilan}

Proses melakukan panggilan juga berjalan dengan sukses ditandai dengan adanya panggilan masuk pada client seperti yang terlihat dibawah. Lalu akan mencul tampilan seperti dibawah ini.

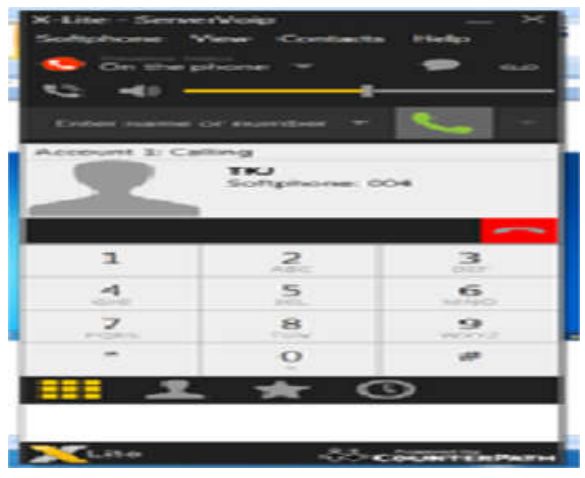

Gambar 10. Panggilan Masuk

\section{Vidiocall}

Vidio call sudah dapat dilakukan ditandai dengan 2 client yang sudah bisa saling bertatap muka seperti yang telihat pada seperti dibawah.

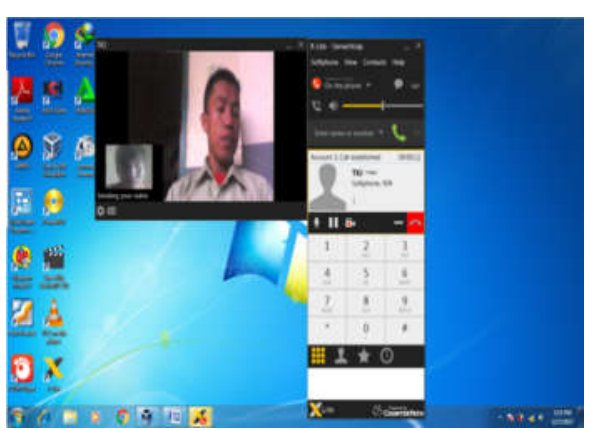

Gambar 11. Vidio call sedang berlangsung

B. Pembahasaan

a. Pengujian Alfa

Pengujian Alfa adalah Yaitu pengujian yang berupa delay waktu yang akan dilakukan oleh penulis dalam hal ini perbadingan dari delay waktu komunikasi voip dan komunikasi menggunakan Whatsapp. Dengan hasil sebagai berikut:

1. Delay telepon VOIP

Delay telpon voip sekitar 3 detik untuk terhubung. seperti gambar dibawah, yaitu pada detik ke 24 panggilan dimulai dan pada detik ke 27 panggilan sudah masuk.

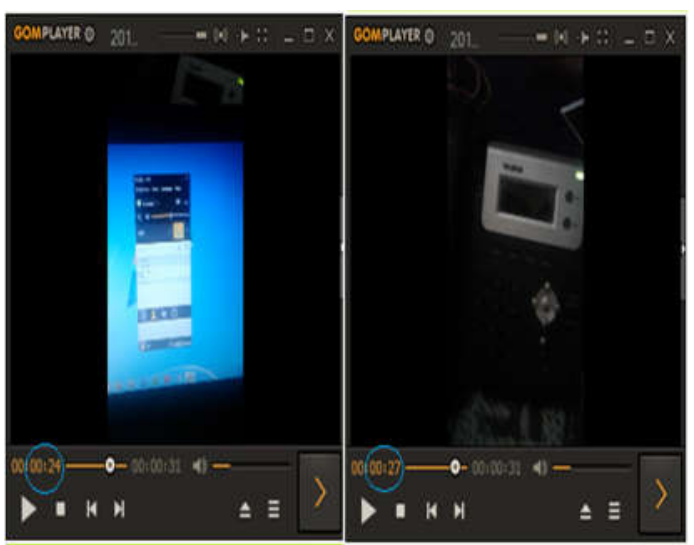

Gambar 12. Delay Telepon VOIP

2. Delay Whatsapp

Delay telpon Whatsapp sekitar 17 detik untuk terhubung. seperti gambar dibawah, yaitu pada detik ke 3 panggilan dimulai dan pada detik ke 20 panggilan baru masuk. 


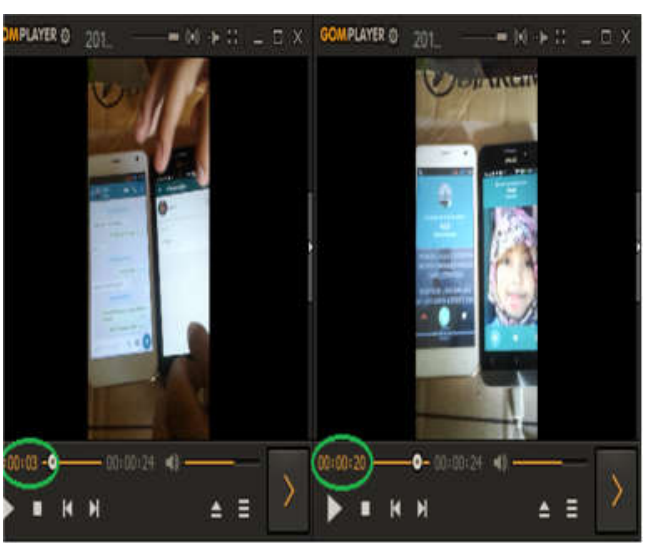

Gambar 13. Delay Whatsapp

Kesimpulan VOIP lebih cepat terhubung dibandingkan dengan Whatsapp.ternyata Voip lebih cepat 14 detik disbanding dengan whatsapp.

b. Pengujian Beta

1. Pengujian Konektivitas

Pengujian Konektivitas dengan menggunakn perintah ping ip Server

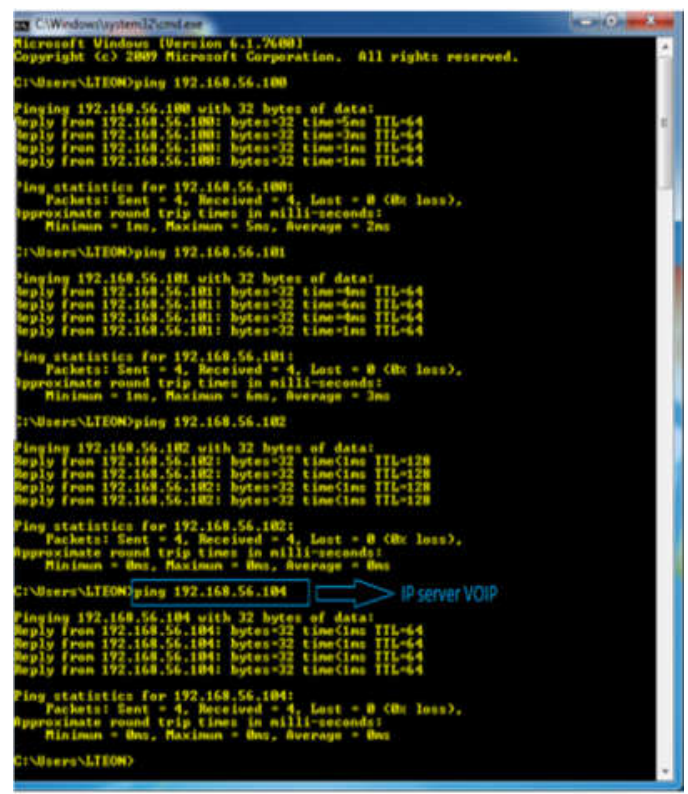

Gambar 15. Server terhubung dengan Client

2. Pengujian Panggilan

Pengujian panggilan dari VOIP Client 1 menuju VOIP Client2 dengan menekan tombol nomor extension yang dituju pada dialpad softphone Client 1. maka pada Client 2 akan muncul nada panggil dan statu panggilan seperti pada gambar.

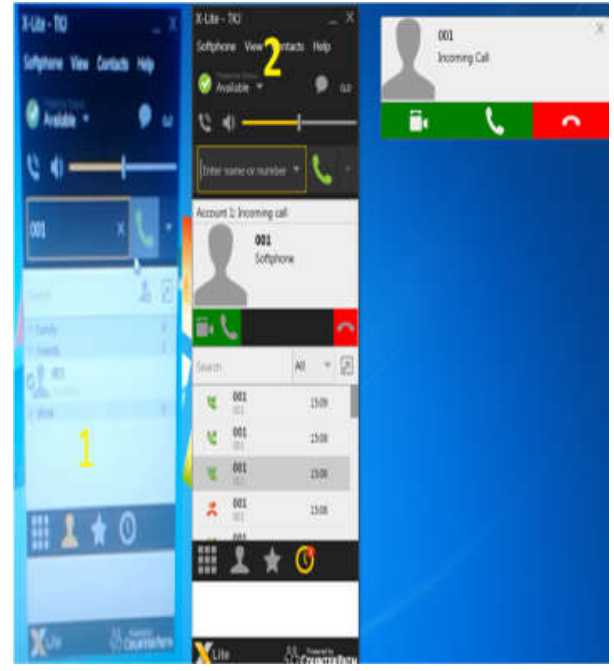

Gambar 16. Screnn Panggilan Keluar dan Masuk

jika sudah ada panggilan masuk maka akan muncul tanda panggilan masuk pada client2, untuk menerima panggilan client2 harus mengkilik Answerr (gambar gagang telepon Hijau) ,apabila mau menolak panggilan maka client2 dapat memilih Reject (gambar gagang telepon Merah). Pengujian panggilan VOIP client1 dan VOIP client2 telah terhubung maka komunikasi suara dapat dilakukan seperti berikut dengan adanya waktu telpon yang dapat dilihat seperti gambar berikut.

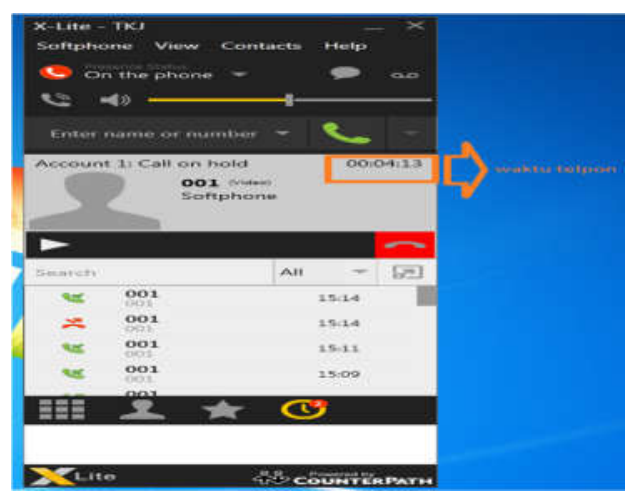

Gambar 17. Screen Panggilan Berlangsung

3. Pengujian Video Call

Pada pengujian Vidio Call dapat dilakukan ketika akan melakukan panggilan dengan cara masukan nomor extension lalu klik tanda panah 
yang ada disamping tombol call pilih video call, jika sudah ada panggilan masuk maka akan muncul tanda panggilan masuk pada client2, untuk menerima panggilan client2 harus mengkilik Icon Camera (di samping gambar gagang telepon Hijau) ,apabila mau menolak panggilan maka client2 dapat memilih Reject (gambar gagang telepon Merah).
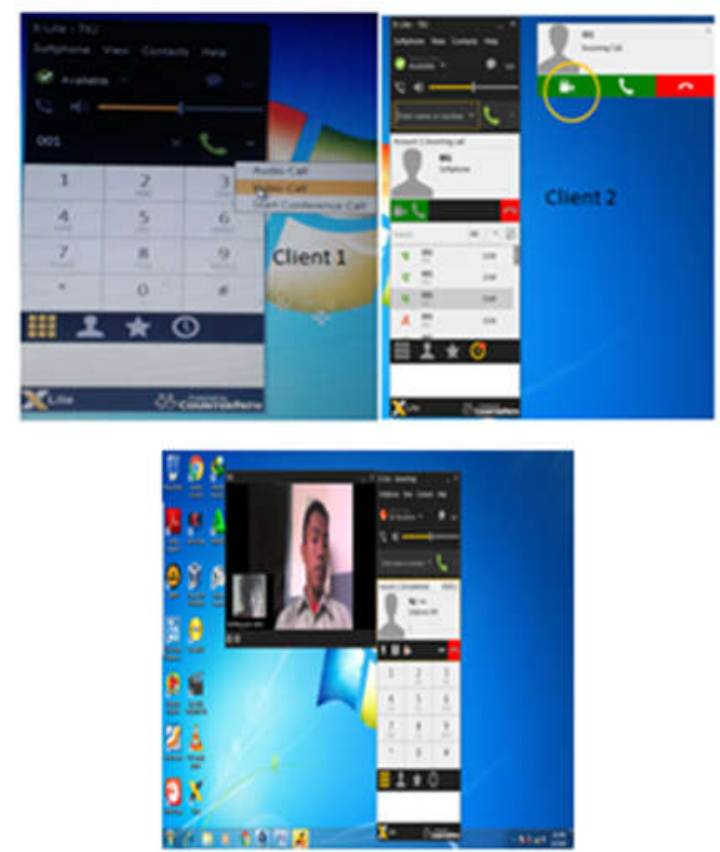

Gambar 18. Screen video call.

\section{c. Hasil Pengujian}

1. Delay atau waktu tunggu telpon VOIP untuk terhubung adalah 3 detik,panggilan dimulai pada detik ke-24 dan terhubung pada detik ke27 pada video perhitungan delay .

2. Delay atau waktu tunggu telpon Whatsapp untuk terhubung adalah 17 detik, panggilan dimulai pada detik ke-3 dan terhubung pada detik ke-20 pada video perhitungan delay.

3. Server dan semua Client yang di Ping dari client1 hasilnya adalah Replay From 192.168.56.104 ( untuk Server ) dan 192.168.56....(untuk Client ) yang menunjukan koneksi terhubung .
4. Client1 dan Client2 terhubung dengan adanya tanda panggilan masuk ke Client2, dan waktu Percakapan mulai berjalan

5. Client1 dan Client2 dapat saling bertatap muka setelah panggilan video masuk ke Client2, dan client2 menerima panggilan video.

\section{KESIMPULAN DAN SARAN}

A. Kesimpulan

1. Pada pengujian Alpha Delay (Waktu Tunggu) telpon VOIP lebih Singkat dibandingkan dengan telpon whatsapp denga perbandingan pada telpon VOIP delay untuk melakukan komunikasi dimulai dari ( detik ke-24 dan terhubung pada detik ke-27) jadi ada 3 detik waktu delay untuk panggilan VOIP dan untuk panggilan Whatsapp dimulai dari ( detik ke-3 dan terhubung pada detik ke-20) maka delay whatsapp adalah 17 detik. Jadi telpon VOIP lebih unggul 14 Detik dari telpon Whatsapp diambil dari selisih delay whatsapp dan voip yaitu 17 Detik - 3 Detik=14 Detik.

2. Pada pengujian Beta Semua client telah terhubung dengan server dan client lainnya,di tandai dengan Replay From 192.168.56.104(Server) dan 192.168.56....(Client). Client1 telah dapat melakukan panggilan suara dan video ke client2. Dan client2 telah dapat menerima panggilan suara dan video dari client 1 .

B. Saran

Adapun saran yang dapat diberikan penulis berupa

1. Pihak sekolah diharapkan menggunakan ISP yang dapat memberikan IP Publik Lebih dari 
Jurnal Pseudocode, Volume VII Nomor 1, Februari 2020, ISSN 2355-5920, e-ISSN 2655-1845 www.ejournal.unib.ac.id/index.php/pseudocode

satu supaya IP publiknya dapat digunakan Untuk Server VoIP agar dapat menghubungkan SMK N 03 dan Cabangnya di pantai panjang.

2. Diharapkan Teknologi VoIP ini dapat di terapkan di lingkungan sekolah saja, tapi juga harus merambah ke masyarakat luas, termasuk universitas.

\section{REFERENSI}

[1] Patih, D. F. J. (2012). Analisa Perancangan Server Voip (Voice Internet Protocol) Dengan Opensource Asterisk Dan VPN (Virtual Private Network) Sebagai Pengaman Jaringan Antar Client. Jurnal Informatika dan Teknik Elektro Terapan, 1(1)

[2] Aditya, Y., Rochim, A. F., \& Widianto, E. D. (2015). Rancang Bangun Sistem Telekomunikasi Konvergen Berbasis Voice over Internet Protocol Menggunakan Virtualbox. Jurnal Teknologi dan Sistem Komputer, 3(2), 282-294.

[3] Aditya, Y., Rochim, A. F., \& Widianto, E. D. (2015). Rancang Bangun Sistem Telekomunikasi Konvergen Berbasis Voice over Internet Protocol Menggunakan Virtualbox. Jurnal Teknologi dan Sistem Komputer, 3(2), 282-294.

[4] Umar, W. (2015). Pengembangan Perangkat Lunak Distribusi Gnu/Linux Dengan Fitur Khas Gorontalo. Simetris: Jurnal Teknik Mesin, Elektro dan Ilmu Komputer, 6(1), 11-16.

[5] Montulli, L., Grobe, M., Rezac, C., \& Dickey, T. www. jurnal-sejarah. com Layanan Informasi 17 Jam.

[6] Hamidi, E. A. Z., Effendi, M. R., \& Widodo, H. W. (2018). Prototipe Layanan VoIP Pada Jaringan OpenFlow. TELKATelekomunikasi, Elektronika, Komputasi dan Kontrol, 4(1), 33-42.

[7] Nama, G. F., \& Septama, H. D. (2016). Analisis Performansi Voice Over Internet Protocol (VoIP) berbasis Session Initiation Protocol (SIP) Pada Jaringan Wireless LAN IEEE 802.11 Universitas Lampung. Masyarakat Telematika Dan Informasi: Jurnal Penelitian Teknologi Informasi dan Komunikasi, 5(1), 85-96.
[8] Muslim, M. A. (2007). Analisa Teknis Perbandingan Router Linux dengan Router Mikrotik pada Jaringan Wireless. Dinamik, 12(1).

[9] Sugeng, W., \& Mery, I. S. (2012). Analisis Jaringan Komputer Dinas Komunikasi dan Informatika. Jurnal Informatika, 3(1), 30-37.

[10] Silitonga, P. (2015). Analisis QoS (Quality of Service) Jaringan Kampus dengan Menggunakan Microtic Routerboard. Jurnal Times, 3(2), 19-24.

[11]ADCOMS. (2015). Membangun System jaringan komputer untuk pemula. Yogyakarta: Penerbit Andi.

[12] Al Arief, M. J., \& Hidayat, I. SHARING DATA ANTARA LINUX UBUNTU DAN WINDOWS MENGGUNAKAN METODE JARINGAN PEER TO PEER.

[13] Wardoyo, I. (2018). Survei Model Performansi Sistem File Sharing BitTorrent pada Jaringan Peer-to-Peer. InComTech, 8(2), 133-150.

[14] Husni. (2004). implementasi jaringan komputer dengan linux redhat9. Yogyakarta: Penerbit Andi.

[15] Pratiwi, P. E., Isnawati, A. F., \& Hikmaturokhman, A. (2013). Analisis QoS Pada Jaringan Multi Protocol Label Switching (MPLS) Studi Kasus di Pelabuhan Indonesia III Cabang Tanjung Intan Cilacap. Purwokerto: Akatel Sandhy Putra Purwokerto.

[16] Wastuwibowo, K. (2003). Jaringan MPLS. Diakses dari http://telkom. info/artikel/mpls-overview. pdf.

[17] Patih, D. F. J. (2012). Analisa Perancangan Server Voip (Voice Internet Protocol) Dengan Opensource Asterisk Dan VPN (Virtual Private Network) Sebagai Pengaman Jaringan Antar Client. Jurnal Informatika dan Teknik Elektro Terapan, 1(1).

[18] Setiawan, D. B., Fatchur Rochim, A., \& Isnanto, R. R. (2011). Voice over Internet Protocol (VoIP) Menggunakan Asterisk Sebagai Session Initiation Protocol (SIP)

[19] Server (Doctoral dissertation, Jurusan Teknik Elektro Fakultas Teknik Undip).

[20] Saputro, B. A., \& Mufida, E. (2015). MEMBANGUN LAYANAN VOIP UNTUK LINGKUNGAN ENTERPRISE MENGGUNAKAN BRIKER IPPBX. Jurnal Teknik Komputer, 1(2), 184-189

[21] Rafiudin, R. (2006). IP routing dan Firewall dalam Linux. Yogyakarta: Andi.

[22] Sanjaya, R. (2012, 08 02). Pengertian Trixbox CE. Retrieved 08 08, 2017, from wordpress.com: http://riansanjaya.wordpress.com

[23] Patih, D. F. J. (2012). Analisa Perancangan Server Voip (Voice Internet Protocol) Dengan Opensource Asterisk Dan VPN (Virtual Private Network) Sebagai Pengaman Jaringan 